\title{
PRAGMATIC IMPLICATIONS OF EXPANDED DEICTIC STRUCTURES: DEIXIS AS AN EXPRESSION OF THE CONCEPT OF FACE IN THE SPANISH PARLIAMENT
}

\author{
Aurelia Carranza Márquez \\ Universidad Nacional de Educación a Distancia (UNED)
}

Resumen: Este trabajo intenta dilucidar las implicaciones pragmáticas del uso de estructuras deícticas expandidas consistentes en estructuras deícticas en tercera persona que tienen como referente una primera persona, dentro de la esfera política española. En particular, analizaremos la estructura "este/a diputado/a" (referente $\rightarrow$ yo) y “este grupo parlamentario" (referente $\rightarrow$ nosotros/as) en el contexto de cuatro sesiones en el congreso de los diputados que tuvieron lugar en 2004 sobre una variedad de temas. El uso mencionado contrasta con la economía del lenguaje, premisa de Grice y del enfoque neo-gricean, que aboga por la prioridad de la eficiencia y la economía en la comunicación desde un punto de vista lingüístico y filosófico. La perspectiva neo-gricean concluyó que las micro y macroestructuras discursivas se debían tener en cuenta (texto y contexto) para poderlas interpretar adecuadamente. En este sentido nos centraremos en aquellos factores e instrumentos de la cortesía, así como de la relevancia, que nos pueda ayudar para identificar la función de este uso particular de la deixis dentro del marco del discurso político. Mantenemos que está conectado con el concepto de imagen (Brown and Levinson, 1987; Goffman, 1967), y que su función es obtener autoridad y valores positivos por parte del hablante. Sin embargo, en algunos casos, tienen un efecto segregador del oponente, a quien se le atribuyen valores negativos por contraste.

Palabras clave: Estructuras deícticas expandidas, discurso político, imagen, cortesía, congreso de los diputados, neo-gricean.

Abstract: This work concentrates on the pragmatic implications of the use of deictical expanded structures consisting on third person indexical structures in relation to first person referents in the Spanish political sphere. Particularly, we will analyze the structure este diputado (this member), (referent $\rightarrow$ I) and este grupo parlamentario (this parliamentary group), (referent $\rightarrow$ we) in the context of four different sessions in the Spanish Parliament held in 2004 referring to a variety of topics. Such use contrasts with the economy of language precept of Grice and the neo-gricean approach, which advocate for the priority of efficiency and economy in communication from a linguistic and philosophical 
point of view. The neo-gricean perspective concluded that micro and macro discursive structures should be considered (text and context) for an appropriate interpretation. In this sense we will focus on those factors and instruments of politeness, as well as of relevance, that may help to target the role of this particular use of deixis in political discourse. We maintain that it is connected to the concept of face (Brown and Levinson, 1987; Goffman, 1967), and it is aimed at the obtaining of authority and positive values of the speaker. However, in some cases, they cause a segregation effect towards the opponent, who is attributed negative values by contrast.

Keywords: deictic expanded structures, political discourse, face, politeness, Spanish Parliament, neo-gricean.

\section{INTRODUCTION}

We are going to concentrate on the pragmatic implications of deictic expanded structures ${ }^{1}$ consisting on third person indexical structures (this member, this parliamentary group) with first person referents (I, we) found in the Spanish political forum. These structures are very significant in the sense that the Spanish system allows the omission of the subject in contexts where they are inherent in the verb's morphology. In this case, first person singular and plural are distinctive and there is no possible misunderstanding in relation to the referent. In the case of our study, not only are the subjects explicit but also more complex structures are being used. We maintain that such behaviour conveys pragmatic implications.

In order to proceed with our study, we have chosen a corpus consisting of four different debates in the Spanish Parliament dealing with four different topics. Such debates are the following:

1. Speech of the Izquierda Unida-Iniciativa per Catalunya Verds Parliamentary Group in relation to gender violence (May 19, 2004), which will be referred as document 1 .

2. Speech of the Secretary of Defence (Bono Martínez) to inform about issues related to the Yakolev 42 crash in Turkey (July 4, 2004) (document 2).

3. Speech of the president of the State-owned Holding Company to the Treasury Committee, in order to inform about the actions of the work group created by the Deputy Government Committee for Economic Issues in charge of analysing the situation of Izar under the Government's petition (July 27, 2004) (document 3).

1 We use the term "expanded" because these structures are artificially prolonged as they refer to single referents. 
4. Speech of the Izquierda Unida-Iniciativa per Catalunya Verds Parliamentary Group about gender violence, second participation (May 25, 2004) (document 4).

These debates meet two main conditions. The first one is that they deal with different issues, which allows us to test the pertinence of the topics and the role of the moral dimension in situations of conflict. Quite unsurprisingly, these structures were found in those contexts in which moral conflicts were at stake. The second condition we have taken into account when selecting the corpus is that that they should be contemporary, as time distance may contaminate the equality requirement we have established as a prerequisite for this comparative analysis. All debates were held in the year 2004 .

\section{INITLAL CONSIDERATIONS}

In order to conduct the analysis we have considered two initial theoretical considerations: (a) the importance of economy in communication and (b) the functions of deixis.

\subsection{The importance of economy in communication}

Different linguistic studies have referred to the economy precept in communication (Cornish 2008; Grice 1967, 1969, 1975, 1989; Horn 1984, 1989, 2004, 2005; Sperber and Wilson 1995, 2002, among other authors).

The structures we concentrate on in this work do not conform, a priori and in general terms, to this precept as they are used in contexts where more simple structures can be used. Furthermore, the Spanish language allows the absence of the subject in a sentence when the form of the verb identifies the subject. For this reason, subject first person singular and plural pronouns are more commonly found in emphatic contexts, which is not the case in the speeches analysed. Therefore, analysing the pertinence of the already mentioned "economy precept" seems evident when dealing with the pragmatic implications of the "deictic expanded structures" under analysis.

We will provide with a brief review of three theories defending the importance of language economy. Carston (2005) compared the philosophies of Grice, the neogriceans, and those embracing RT (relevante theory), all of them dealing with low cost functionality of language, in his work "Relevance Theory, Grice and the neo-Griceans: a response to Laurence Horn's "Current issues in neo-Gricean pragmatics". We will refer to his comparisons in our work.

Sperber and Wilson $(1995,2002)$, the fathers of the Relevance Theory, maintained that human cognition tends to select relevant inputs whose processing costs are reasonably low. According to RT, linguistic utterances are presupposed to attain a certain level of relevance, that is, they imply an acceptable cognitive 
benefit for no unnecessary processing effort. This entails an intentional agent and intention to provide relevant information. However, this proposal has been clarified by later studies.

Grice, also in this line of thought, described a number of maxims of quantity which, according to him, contributed to fluency and effectiveness in communication. This author, as well as Sperber and Wilson, assumed a speaker whose intention is to affect the hearer. (Grice 1975, 1989).

Subsequently, Horn specified that the goal of the Gricean theory was to explicate speaker meaning, or, more specifically, 'to characterize implicature as part of speaker meaning' (Horn 2005a: 192). However, as Carston indicates, Neale (1992: 509) provided with a further clarification. He specified that Grice's philosophy of language consisted of at least the following four processes:

- to elucidate the meaning of an expression e, what a speaker $\mathrm{S}$ said on a particular occasion by uttering e, and what $S$ meant when s/he uttered e on that occasion.

- to understand the nature of non-natural meaning by analysing sentence meaning, the speaker's meaning, and what is said.

- to explain how what $\mathrm{S}$ says and what $\mathrm{S}$ means may differ.

- to differentiate between semantic content and pragmatic implications.

Horn's perspective is mainly linguistic as he concentrates on the relation between grammar and pragmatics; he analyses how pragmatic factors may affect lexicalisation, for instance, by promoting abbreviation of certain frequently used forms in order to save speaker's effort (see Horn 1984, 2004). He concentrated on two kinds of conversational implicature. One of them derives from his RPrinciple (minimizing speaker's effort), and the other one from his Q-Principle (minimizing hearer's effort). However, their perspective is quite different from that of Grice. For Carston (2005), "While his system [Horn's] is not intended to provide an account of utterance processing like RT, nor does it have Grice's philosophical analytical concerns". Carson concludes his comparison of the Gricean, the neo-Gricean (Horn) and the relevance-theoretic in a very clear way. He explains that they deal with the same issue although from different disciplines: Grice with philosophical analysis, Horn with linguistics, and RT with cognitive processing, all of them coinciding in the way they stressed language efficiency and functionality. Taking into account their theories, our view is that the structures under analysis are not gratuitous. They are meant to cause an effect on the addresses and thus we consider them linguistic strategies whose effects will be the main concern of this work. 


\subsection{The functions of deixis}

Different functions of deixis have been described; social deixis may have a distinctive function in social relations. Within this typology we find the use of pronoun usted, a polite form indicating respect and the recognition of a certain social status of the addresse. Also, we could mention exoforic deixis (ad oculos), empathetic deixis (emotional or psychological "distance" or "proximity" between a speaker and a referent), personal deixis, referring to the role of participants (I, we, our, mine...), temporal deixis, spatial deixis, and so on.

From the point of view of pragmatics, deictics depend on the speaker's context, on extralinguistic elements, for their correct interpretation. For instance, if we are told: "you must let him know about this issue", and we are not familiar with the context, we will not be able to understand the meaning of the utterance. Or as Widdowson and Jaszczolt put it: "The text is always incomplete and indeterminate in relation to the discourse which may be derived from it with the help of a context" (Widdowson, 2004:8; Jaszczolt, 2005:13).

However, Kaplan (1989) defended the existence of a subgroup he called pure indexicals, such as "I", "you", "here", "today", which do not convey pragmatic implications in the sense that the speaker's intentions are clear as they are supplied directly by the narrow semantic context of the utterance. In this sense, we consider that the use of expanded structures in contexts where "pure indexicals" apply must have a pragmatic value.

We should take into account that the main difference between pure indexicals and demonstratives (the elements introducing the expanded structures of our analysis) is that it is the speaker's intention that determines the reference of a demonstrative, not a fixed function of external features of the context of utterance. Pure indexicals are different from demonstratives in the sense that their referents are inherently distinctive whereas demonstratives may convey the following possibility: "A is X" and "A is not X". Thus, in theory, a person could not think of himself/herself as two different people at the same time.

In our work, speakers break this rule as they present themselves figuratively in a schizophrenic way: from a semantic perspective, as the speakers of the utterance, and from a pragmatic view, the psychological distance created by a third person structure portrays a referent apparently detached from the person who is speaking. The segregating effect of such strategy provides a new contextual dimension related to role discourse and the position of the speaker in relation to what $\mathrm{s} / \mathrm{he}$ is saying.

Role discourse must be taken into account at this point as the expanded structures analyzed (this member, this parliamentary group) are related to the community of practice (Lave and Wenger, 1991; Wenger 1998) to which speakers and interlocutors belong to. They are all members of the Spanish Parliament. It is quite paradoxical but this segregating structure conveys an integrating effect. It is in this context that politeness (Brown and Levinson 1987) and the 
concept of face (Goffman 1967) apply. In particular we will concentrate on the concepts of positive and negative face. According to Brown and Levinson positive face is "the want of every competent adult member that his action be unimpeded by others" and negative face is described as "the want of every member that his wants be desirable to at least some others" (1987: 62).

In our study, all the interlocutors have a special interest in their proposals to be accepted in a context of power imbalance. Although all the participants in the debates are members of the Parliament, not all the groups have the same relevance or representation and all of them want their voices to be heard by their colleges and, at the same time, want to please their voters and their expectations. In this sense, the concepts of positive and negative face are of great interest.

\section{ANALYSIS}

This analysis has been conducted in the following manner: first, we have identified the forms under study and then we have concentrated on the context in which they appeared and the possible causes and effects of such usage. We start with the structures referring to a first person referent, "this member".

\subsection{First person referent "I" $\rightarrow$ this member}

Document 1

Example (a)

Pg 333.- (IU) Sra. García Suárez: No queremos - y no va a ser el estilo de esta diputada- hacer una intervención en la que se reiteren aspectos que ya han sido tratados. Queremos hacer una intervención clara, directa y que aborde aspectos diferente

Ms García Suárez: We do not want - and it is not going to be the style of this member-to make a speech in which aspects already dealt with will be reiterated. We want to make a clear and direct speech dealing with different issues.

Example (b)

Pg 334.- (IU) Sra. García Suárez: Sin caer en valoraciones exageradas ni dramáticas, que no es la intención de esta diputada, que siempre propondrá hablar menos de violencia y actuar más a favor de la convivencia, quisiéramos dejar claras un par de cosas.

Ms García Suárez: Without making exaggerated and dramatic evaluations, which is not the intention of this member, who will always suggest talking less about violence and working more in favour of coexistence, we would like to clarify a few things. 
The first thing that calls our attention is the syntactic distribution of these sentences. The expanded structures under study are found in a peripheral position, between commas, as a clarification of the main sentence.

It is also remarkable that the speaker delivers her speech through a first person plural subject, "we do not want", "we want to", "we would like", all of them structures with verbs of volition, which clearly portray the nature of her discourse. She is presenting her intentions and those of her political group. She enters a dimension in which she expresses what is desirable, or maybe correct, for her group and what is not, thus, offering a moral characterization of herself and of the group she is representing in that precise moment. Her discourse is uttered from the perspective of her group and it is only in some clarifications that we find the expanded structures (herself as an individual).

Also, expanded structures appeared in negative constructions, counteracting a situation the speaker finds undesirable. They can be interpreted as redress structures in which the speaker anticipates criticism and justifies herself in front of an audience that may find her discourse incoherent. Maybe for this reason she stresses her own behaviour in opposition to other people or other groups. We find the dichotomy "I do not do X, others do X", "this" as an element in opposition to "that" or "those", even if they are not overtly expressed. This assumption implies that other people do not behave in a correct manner, as the speaker does. In this sense, maybe we should clarify this structure as "an indirect redress structure" as it justifies her behaviour at the same time as it also implies a confrontation with those who do not share her "style".

In any case, these structures, which from now on we will call $\mathrm{ExS}$, reinforce the assertions made in the name of the group represented.

Through the use of this structure the speaker enhances her condition of a "member" in a situation where she is presenting herself as a person with morals and anticipates the reaction of other "members" whose morality may not correspond to hers. It is a complex strategy. On the one hand, she stresses her membership to a group where her interlocutors also belong to. At first, we may think that she is reinforcing her positive face but the covert contrast "this/that" insinuates an overt gap between subgroups. Also another gap is evidenced, on the one hand what she says, and on the other hand what she does not mean with what she says: "which is not the intention of this member", "it is not going to be the style of this member".

Example (c)

Pg. 334.- (IU) Sra. García Suárez: Si bien, como ya ha explicado esta diputada, eso sólo hubiera repercutido en una cuarta parte de las mujeres muertas el año pasado. 
Ms García Suárez: Although, as this member has already explained, that would have only had an effect on one fourth of the women murdered last year.

In this example we find an $\mathrm{ExS}$ in an affirmative context. However, it has a commonality with those appearing in negative ones. This structure ("this member" $\rightarrow$ fist person referent) consistently appears peripherally. Thus we should think that in this case it also has a clarifying and reinforcing goal. The statement, "as this member has already explained", has a reiterative nature that gives coherence to the speaker's line of argument through the recurrence of her (Ms García Suárez) behaviour in different situations; present as a natural extension of the past (Duranti 2006), thus providing with temporal coherence and using repetition as a persuasion strategy. Also, it is relevant to notice that the speaker is denouncing something that did not work, so she is reinforcing a previous criticism.

\section{Document 2}

Example (a)

Pp.10-11-Sr. Mardones Sevilla (Coalición Canaria): Vaya por delante que, señor Ministro de Defensa, que usted acaba de realizar una delimitación que a mi me parece acertada: no entrar en una exigencia de responsabilidades políticas [...]. En la comparecencia del señor Ministro de Defensa entonces, don Federico Trillo, ante esta Comisión, en la pasada legislatura, el 4 de junio, este diputado que habla ahora en nombre del Grupo de Coalición Canaria, servidor de ustedes, dijo textualmente: Pero el tercer escalón son las responsabilidades, y si las culpas no están dentro del Ministerio de Defensa, las responsabilidades, las que sean, si parece que están dentro del mismo. Mr Mardones Sevilla (Canary Islands Coalition): I must say that, $\mathrm{Mr}$ Minister of Defense, you have just made a demarcation that I find very wise: do not call for political responsibilities [...]. During the speech of the former Minister of Defense, Mr Federico Trillo, in this committee, the past term of office, on June 4, this member that is speaking now for the Canary Islands Coalition Group, your humble servant, said word for word: but the third step are responsibilities, and if the Ministry of Defense is to blame, responsibilities, whatever they may be, seem to be [dealt with] within the Ministry.

Here we find an intervention reinforced through what we could call an "out of breath" strategy due to the length of his sentences, but first we should mention that the speaker is talking about an issue that has provoked great confrontation in the Spanish political and social sphere. Sixty-two Spanish soldiers died in a plane 
crash and this committee is trying to decide who is to blame, and especially to which extent the previous Minister of Defense should be to blame and punished for not making sure that the soldiers travelled in safe planes, if that was the case or just an unfortunate accident. Whether it could have been prevented or not is the main issue at stake. Different groups have different opinions and conflict is on the table. Redress in this context of confrontation is achieved here by the breaking of the Maxim of Quantity. The length of the ExS, "this member that is speaking now for the Canary Islands Coalition Group, your humble servant, said word for word", is remarkable. It is expanded in four ways:

- the speaker reinforces the moment of the speech, the present time, "is speaking now", indirectly creating a contrast with the past.

- he specifies his parliamentary group, "for the Canary Islands Coalition Group", singularizing his identity within the forum through the specification of his group, a minority group, and also legitimizing his condition of member of "the community".

- he adds what we could call a "chivalric expression" indicating a collaborative attitude, "your humble servant", and resulting in the reinforcement of his positive face.

- he emphasises the accuracy of what he is going to say, which is exactly something that had been said in a previous occasion. In other words, he insists in the fidelity of his memory ("word by word") and also in the fidelity of his behaviour, strategy already used in the previous example although here in a more exaggerated manner. Thus, his emphasis on the creation of the dichotomy present/past is especially productive.

Tension here is not as evident as in the previous example where the intention was to denounce something that did not work. Mr Mardones Sevilla is defending the view of his group through the elaboration of a coherent discourse. Criticism is not remarkable in this example. The speaker represents a minority group and through the enhancement of his positive face, and that of his group, he is presenting his contribution as valuable in a forum where the two main political groups, the socialist and the conservative ones, have more importance in the final decisions than the rest of groups. Mr Mardones Sevilla is setting a context where his group can be taken into account as an objective and coherent participant in the making of decisions.

\subsection{Third person referent "I" $\rightarrow$ this Parliamentary Group}

We have found only one example in the documents under analysis. However, as we will see, its nature and use is different from that of the ExSs previously analyzed. 


\section{Document 1}

Pg. 334.- (IU) Sra. García Suárez: Aqui en este punto este grupo parlamentario no puede dejar de hacer bincapié en la enorme responsabilidad que tienen los poderes públicos $y$, con ello, las diferentes administraciones del estado [...] debemos dejar a un lado la hipocresía y los planteamientos políticamente correctos.

Ms García Suárez: Here, at this point this Parliamentary Group cannot give up stressing the huge responsibility of the public powers together with the different State Administrations [...] We must leave behind hypocrisy and politically correct approaches.

Contrary to what we have seen in the previous cases, the $\mathrm{ExS}$ used here is not separated from the rest of the sentence. Furthermore, it expresses the climax of the intervention as the speaker explains the main idea of her group. This strategy reaffirms group identity and reinforces their position.

Likewise, the speaker's negative argumentation, "this Parliamentary Group cannot give up stressing...", involves the idea of a correct attitude in opposition to an incorrect one. The use of modal "cannot" indicates obligation, thus implying a dichotomy of moral behaviour and political responsibility.

\section{CONCLUSION}

To begin with, it is quite remarkable that these structures have not been found in all the documents analyzed. They appeared in those with moral implications and, most important, with a great impact on society, thus, they are related to the view that society may have of the morals of the Parliamentary groups and their members. In particular, they were found in relation to the issues of the gender violence and the death of 62 Spanish soldiers in a plane crash as they were returning to Spain from Turkey.

Such factor is also appreciated in the effort of the speakers to present themselves in a positive manner in front of their audience in a situation of conflict. This fact can be observed in the negative structures that denote a dichotomy and two different behaviours, one correct and one incorrect.

Likewise, we have found some differences in the structures with a singular referent (peripheral characterization-reinforcement of positive face) and a plural one (central structure-climax).

The ExS "this member" could be considered a "safe" option of impoliteness as the referent is expressed under cover. The speeches analyzed were all articulated through the first person plural subject we and the ExSs functioned as a personal "side comment" equivalent to a declaration of principles in which all the interlocutors are not included. We should take into account the cover dichotomy this/that. We have taken such dichotomy for granted as the speeches take place 
in a context of conflict. The individualizing effect of this structure in a collective linguistic environment (we) convey a clear contrast, especially when moral behaviours are at stake, that provide the speaker with an extra moral contribution that indirectly also enriches her/his political group. It is a strategy, then, that overtly reinforces the positive face of the speaker through allusions to the role that all interlocutors share (members) but at the same time with the intention of making his/her view more attractive through the contrast moral/immoral, correct/incorrect.

However, we have also found an example in which the combative nature already mentioned was not so clear. The speaker's intention rather than criticizing the behaviour of others seems to legitimate his value as a person and that of his group in the discussion that is taking place. This was explained on the basis of the minority nature of the group represented and its claim to have a productive role in the discussion. The contrast this/that is observed, but it does not seem to clash any other political group openly.

The case of the ExS "this Parliamentary group" is completely different. From a linguistic point of view, it does not contrast with the articulation of the speech as they continue the use of the first person plural referent (we). Also, it does not appear separately from the main utterance, furthermore, it expresses the main idea of the intervention. Our interpretation is that this structure emphasizes the collective nature of the intervention and the membership to the community in charge of the discussions. Thus, the positive face of the whole group is reinforced making their view more persuasive. Cover contrast is also appreciated as it seems to be one effect of the use of the deictic. Such contrast has two main implications: (a) the group of the speaker is morally reinforced as the assertions made when these structures are found are relative to an exemplary behaviour, and (b) contrast has a reinforcing effect as it implies a lack of homogeneity in the community where the speakers operate, thus, their behaviour being even more laudable.

Also, we have not found a great variety of speakers who used these structures. Therefore we could think that it is a matter of "linguistic personal style".

At this point we can conclude that the ExSs analyzed have a clear pragmatic value. It is a strategy oriented towards the protection of the positive face of the speaker in situations of conflict where the "moral self" is catalyzed through a deictic structure that unites opposite values of integration and segregation of the different groups that are part of the Spanish Parliament.

\section{BIBLIOGRAPHY}

Brown, P. and S. Levinson (1987). Politeness: Some Universals in Language Use. Cambridge: Cambridge University Press. 
Carston, R. (2005). "Relevance Theory, Grice and the neo-Griceans:a response to Laurence Horn's "Current issues in neo-Gricean pragmatics" Intercultural Pragmatics 2(3), 303-319.

Cornish, F. (2008)." Inter-sentential anaphora and coherence relations in discourse: a perfect match." Language Sciences, 32(3).

Duranti, A. (2009). Linguistic Anthropology: a Reader. Oxford: Wiley-Blackwell.

Goffman, E.. Interaction Ritual. Pantheon: New York, 1967.

Grice, H. P. (1967). "Logic and Conversation" (William James Lectures, Harvard University).

—, (1969). “Utterer's Meaning and Intention.” Philosophical Revieww, 68, 147-77.

—, (1975). "Logic and Conversation." The Logic of Grammar, ed. Donald Davidson and Gilbert Harman (Encino, Cal.: Dickenson).

—, (1989). "Studies in the Way of Words", Harvard University Press, Cambridge, Mass.

Horn, L. (1984). Toward a new taxonomy for pragmatic inference: Q-based and Rbased implicature. In Schiffrin, Deborah (ed.), Meaning, Form and Use in Context (GURT '84), 11-42. Washington: Georgetown University Press.

-, (1989). A Natural History of Negation. University of Chicago Press.

-, (2004). Implicature. In Horn, Laurence and Gregory Ward (eds.), Handbook of Pragmatics. Oxford: Blackwell. 3-28.

-, (2005a). Current issues in neo-Gricean pragmatics. Intercultural Pragmatics 2 (2): 191-204.

-, (2005b). The border wars: a neo-Gricean perspective. In Turner, Ken and Klaus von Heusinger (eds.), Where Semantics meets Pragmatics. London: Elsevier.

Jaszczolt, K. (2005) Default Semantics: Foundations of a Compositional Theory of Acts of Communication, Oxford: Oxford University Press.

Kaplan, D. (1989). "Demonstratives." In Almog, Perry, and Wettstein 1989, pp. 481-563.

Lave, J.; Wenger, E. (1991). Situated Learning: Legitimate Peripheral Participation. Cambridge: Cambridge University Press.

Neale, S. (1992). Paul Grice and the Philosophy of Language. Linguistics and Philosophy 15: 509-559.

Sperber, D. and D. Wilson. (1995). Postface. Relevance: Communication and Cognition. Second edition. Oxford: Blackwell; Cambridge, Mass.: Harvard University Press.

-, (2002). Pragmatics, modularity and mind-reading. Mind and Language.

Wenger, E. (1998). Communities of Practice: Learning, Meaning, and Identity. Cambridge: Cambridge University Press

Widdowson, H. (2004).Text, Context, Pretext: Critical Isssues in Discourse Analysis. Oxford: Wiley-Blackwell Publishing.

Zipf, G. K. (1949). Human Behavior and the Principle of Least Effort, Cambridge: Addison-Wesley. 